\title{
Гукасова М.М. \\ Очерковая публицистика как часть персонализации медийного творчества Василия Пескова
}

Кубанский государственный университет (Россия, Краснодар)

doi: 10.18411/spc-25-01-2018-02

idsp: 000001:spc-25-01-2018-02

Авторская точка зрения в художественно-публицистических жанрах доминирует. Она подчиняет себе все остальные позиции. Во внутренней речи текст сжимается в концепт (представление), содержащий смысловой сгусток всего текстового отрезка. Концепт хранится в долговременной памяти и может быть восстановлен в словах, не совпадающих буквально с воспринятыми, но таких, в которых интегрирован тот же смысл, который содержался в лексическом интеграле полученного высказывания [2]. Посредством использования языкового богатства, журналисту удается не только описать четко и точно происходящие действия, явления, характеры и образы героев-персонажей, но и проявить свой собственный стиль, что делает его авторские публикации более узнаваемыми. Именно здесь зарождается индивидуальная величина популярности журналиста.

Для наглядности обратимся к медийному творчеству В.M. Пескова. Оригинальность его публицистических книг заключается в попытке разгадки одной из вечных тем «человек-природа», в их сложных взаимоотношениях, где природа всегда является субъектом, а человек - объектом.

Василий Песков умеет видеть, слушать, чувствовать природу нашей Земли и пишет о ней свежо, сочно, подлинно. Песков много фотографирует. Он часто охотиться с фотообъективом за лесными загадками. В поле, в лесу он свой человек. Он все время напоминает: вы тоже можете стать «своим человеком». Лесной праздник доступен всем. «На этот праздник не нужен билет. Кладите краюху хлеба в мешок, проголосуйте попутному грузовику, или садитесь в автобус, или велосипед седлайте, а лучше пешком. Пораньше из дому, лучше с самой зарей. Тогда весь праздник - ваш. Вы увидите, как стягивает солнце туманное одеяло с реки, увидите росу на красных осиновых листьях, увидите, как добывает свой «хлеб» трудолюбивый дятел. Не заявляйте о себе криками, приберегите песни. Слушайте тишину, и тогда осень лесная покажет вам все богатство...» [7].

В.М. Песков очеловечивает природу, приближает ее вплотную к миру людей. В этом контексте интересен рассказ автора о птицах, где он, в беседе с читателем представляет их как своих знакомых или подопечных: «нам приходится только дивиться, как эта ласточка, улетающая на юг, находит весной обветшалый сарай, свой бывший роддом...», «выведенная в инкубаторе и воспитанная при отсутствии общества себе подобных птица...», «однажды в гости к бабушке-рыси...», «еще более близкие родственники - собаки иволки», «белотелую дездемону (более того, сравнение с героиней шекспировской трагедии) приголубил в зарослях дикий кабан», «видно, очень уж нравились темнокожему ухажеру породистые блондинки...» (о свинье и диком кабане), «киты - большие путешественники», «сверкающий наряд петуха», «Гоша (грач) - инвалид» (ну как тут не вызвать жалость у читателя?!), «а детишки куницы тоже играют в кронах деревьев...» (нежное сравнение с малышами, которых в человеческом мире любят до безумства), «Для ночлега белобокие птицы выбирают нестарые ельники и, прежде чем в них нырнуть, совершают «вечерний молебен...» (ритуалы бывают и в птичьем мире), «Родители-вороны - очень прилежные» (невольно вызывается у читателя уважение к этой птице в траурном окрасе), «птенцы пингвинов, рожденные в Антарктиде зимой, спасаются от морозов, сбившись в плотную массу «детские сады». Кабаны спят, тесно прижавшись друг к другу. Коллектив - великая сила!». Особенное таинство природы, считает В.Песков, - это пение птиц. У читателя 
возникает ощущение, что автор является тоже птицей, но только главной - дирижером «единого хора радости», который обнаруживает «тончайшие оттенки в пении птиц», сравнивая эту песню с «разговорным языком», выражением способа «не потеряться в лесу». Пение птиц очеркист сравнивает с «демонстрацией жизненных сил» и «радостью любви». Понимая и принимая загадочное звуковое исполнение братьев наших меньших, В. Песков выводит философскую формулу, тем самым призывая и своего читателя к высоким нравственным, духовным вершинам, предлагая ему задуматься над вечностью бытия: «Это просто крик жизни: «Я вижу солнце, я радуюсь, что живу!». Только такая любовь к природе и привязанность к ней побуждала В. Пескова подписывать свои книги символичным изображением себя и птички, несущей в гнездо червячка. Для многих ворона - птица чёрного цвета со зловещим криком, демонична, связанная с царством мёртвых, питающаяся падалью, но только не для Василия Пескова, который считает, что для «человека северного ворон - товарищ, друг, брат и даже более - божество. А как же иначе. С выпадением снега исчезают почти все птицы. А ворон остается. Он всегда на виду и делит с человеком тяготы долгой зимы. Он держится возле домов, как курица, сопровождает охотника, зная: удачный выстрел и ему что-нибудь принесет [8]. Или защищая имидж сороки, выстроенный в сознании человека как птицы-воровки, В. Песков пишет: «Сорока - великолепный строитель. Ее гнезда обнаруживаешь, когда лес потеряет листву. Висят на ветках, как мохнатые шапки, и кажутся легкими. Но, запустив в гнездо руку, находишь в жилье плотный глиняный пол, а под ним шарообразный шатер из веток, охраняющий дом от всех, кто хотел бы в него проникнуть с недобрыми целями. Строительство гнезд у сорок идет споро. И они, как правило, не стремятся повторно его использовать. Вывели птенцов и прощай! Гнездо остается неумехам - совам, куницам, маленьким соколам - и служит несколько лет». Используя принцип комплиментарности, В. Песков далее добавляет: «Сама сорока - обидчица очень многих. Стоит ей заприметить чье-то гнездо - в тот же день оно опустеет, ворует сорока яйца, уносит птенцов. Есть у белобокой щеголихи странная слабость ко всякого рода блестящим вещицам - носит в гнезда кусочки фольги, стеклышки, пуговицы, могут заинтересовать птицу лежащие на подоконнике часики или колечко. Одним словом, сорока-воровка». Но благодаря песковскому языку читатель узнает больше о сороке-созидателе, и поэтому образ воровки смягчается положительной характерной деталью птицы-строителя. Пользование языком накладывает ответственность. В человеческом языке воспринимаемый «прочий мир» созданий становится предметом рефлексии. В ее основе лежит название животных по видам. Из всего повествования книги Бытия следует, что человек в своем познании несет двоякую (двуединую) ответственность: ответственность перед Создателем и ответственность за создания. Язык способен служить человеческой коммуникации (между «я» и «ты»), косвенно говорит о том, что его смыслом является взаимопонимание, а не разрушение [4].

В очерке «Обыкновенное чудо» автор, называя воду «одним из самых ярких чудес природы», рассказывает о той величайшей силе воды, которая «рядом с нами» с момента рождения. «Считают, жизнь на нашей планете зародилась в воде. И не случайно кровеносная жидкость в сосудах животных и человека близка по составу к морской воде... А сколько радости дают человеку чистые воды бегущих горных ручьев и речек, зеркальная вода озер, обрамленная кувшинками и пахучими травами. Человек, выраставший возле воды, уносит из детства самые радостные впечатления - рыбалка, лодка, коньки зимой, купанья, наблюдение за таинственной жизнью в воде и возле воды», - пишет автор. Объясняя научно-популярным и художественным языком, что такое вода, и какую роль она играет в жизни планеты, автор незаметно подводит нас к проблеме: «Хуже всего то, что после использования человек возвращает в природу загрязненную воду. Она еще годится на технологические процессы, но жизнь в ней бедна или вовсе отсутствует. А для питья текущие воды даже при очень дорогой и громоздкой очистке во многих местах уже непригодны. И есть места на земле, где воды просто хронически не хватает. Засухи длятся тут многие лета, и земля 
опустынивается...». Автор поднимает глобальную проблему человечества. Без определенного количества воды в день жить человек не может. Он призывает людей изменить отношение к воде, ибо люди совершенно не понимают, что вода - это тоже дар Божий и требует бережного и экономного отношения к себе. Вот какое это чудо, какая «это ценность - ВОДА». Публицист приводит цитату восточного мудреца Назыма Хикмета, который говорил о предпочтенье воды изысканным винам. Но можно и шире понять его мысль: «без здоровой воды немыслима здоровая жизнь на земле» [9]. Поднимая проблемы нравственной чистоты экологии, публицист считает, что «Природа - законодатель вкуса, красоты, совершенства. В природе проходит воспитание художников...». В качестве самого общего критерия наличия философского содержания в медиатексте, Р.Р. Москвина определяет следующее: «Писатель (поэт, художник), применяющий к действительности идею как «высшую точку зрения» (а в этом и состоит одна из важнейших общественных функций искусства), по необходимости выступает как писатель-философ, а его творчество - как художественная (литературная) форма философствования» [6]. В жизни всегда происходит борьба добра со злом, нового со старым, прогрессивного с реакционным, отжившим. Умение определить конфликт как движущую пружину общественного развития, человеческих поступков, различных явлений природы, и на основе этого драматургически выстроить свое произведение - вот один из главных секретов профессионального мастерства журналиста [14]. Василий Песков считал, что журналист должен быть свободным, но обязательно нести ответственность перед обществом и Природой. Здесь, по мнению отечественного философа Ю.Б. Мелих, проблема свободы переносится в плоскость заданности личности Богом, а не только зависит от бытия. Божественность, как условие тварного бытия, а не тварь как таковая, определяет Божественный замысел, человек же свободен сделать Божий замысел своей целью [5].

Высоко оценивая способности В. Пескова отражать в своих выступлениях наиважнейшие проблемы времени, для которого умение писать и снимать «открывается одним и тем же ключом», Леонид Леонов называл его «солдатом мира и солдатом природы», как «верного, вдумчивого и бескорыстного друга зверей и зверушек» [3].

Человек не может обособиться от всей природы, от природного мира в целом. Созидательное отношение человека к природе выражается в том, что человек не берёт из природы безвозвратно, а сам обогащает природу. Безлично-социальное отношение к природе губительно как для природы, так и для человека. Оно должно быть заменено личностно-индивидуальным отношением.

$$
* * *
$$

1. Афанасьева Н. Василий Песков - журналист, который не перестал удивляться. 13.08.2013. РИА Новости

1. http://ria.ru/analytics/20130813/956028884.html\#ixzz4EsZe0KhK

2. Жинкин Н.И. Речь как проводник информации. М.: Наука, 1982.- 160. С. $48-49$.

3. Леонов Л. Отечество // Публицистика. - М., 1987. С. 535-536.

4. Мелих Ю.Б. Поиск трансцендентальных оснований индивидуального и общего в творчестве. / История философии №19, 2014.

5. Мелих Ю.Б. «Сущее личности и личностность единосущего. К вопросу о спорности персонализма у Л.П. Карсавина и Н.А. Бердяева». Вопросы философии. 2008. №8. С. 145-157.

6. Москвина Р.Р. «Смешанные» жанры словесности как эмпирия философствования// Вопросы философии. 1982. № 11. С.108.

7. Песков В.М. Полное собрание сочинений. Том 21. Мир на ладони: «Комсомольская правда», Москва. 2014.-541c.

8. Песков В.М. Полное собрание сочинений. Том 19. Про братьев меньших: «Комсомольская правда», Москва. 2014.-557c.

9. $\quad$ Песков В. Речка моего детства. Комсомольская правда. 29 ноября, 1970.

10. Покорны П. Язык в точных и гуманитарных науках, включая теологию/ Вестник СанктПетербургского университета, 2015. №4. Сер.9, с.11. 